\title{
STRUCTURE OF THE ECONOMIC COMPETENCE \\ OF BACHELORS OF ENTREPRENEURSHIP, TRADE, AND EXCHANGE ACTIVITY OF THE EDUCATIONAL PROGRAM "COMMODITY AND COMMERCIAL ACTIVITY»
}

UDC 378-057.87:658]-047.22

DOI: $10.12958 / 2227-2747-2020-2(174)-35-44$

Morozova Mariia Mykolaivna,

Ph.D. (Candidate of Pedagogical Sciences),

Associate Professor of the Department of Commodity,

Trade Entrepreneurship, and Examination of Goods,

Luhansk Taras Shevchenko National University,

Starobilsk, Ukraine

mariya.2186@gmail.com

https://orcid.org/0000-0001-7485-0102

To cite this article: Morozova, M. M. (2020). Structure of the Economic Competence of Bachelors of Entrepreneurship, Trade, and Exchange Activity of the Educational Program «Commodity and Commercial Activity». Osvita ta pedahohichna nauka - Education and Pedagogical Sciences, 2 (174), 35-44 [in Ukrainian].

Formulation of the problem. The state of the economy and the features of the functioning of the socio-political, socio-cultural environment in Ukraine determine the high requirements for the professionalism of future specialists in the field of entrepreneurship and trade in the labor market. Involvement of Ukraine in the process of European integration, intensification of cooperation on the territory of the World Trade Organization contributes to the development of trade relations, which leads to an additional demand for highly qualified specialists who can provide an economically feasible cycle of circulation of goods from the manufacturer to consumers in both domestic and foreign markets. Such specialists are potential applicants for higher education in the specialty 076 «Entrepreneurship, Trade, and Exchange Activity».
According to the $\mathrm{Na}$ tional Strategy for the Development of Education in Ukraine for the period up to 2021, «the modern labor market requires from the graduate not only deep theoretical knowledge but also the ability to independently apply it in non-standard, changing life situations, the transition from a knowledge society to a society of vital competent citizens». (National Strategy, 2013). The professional training of future specialists should focus on «updating the goals and content of education using a competency approach and personal

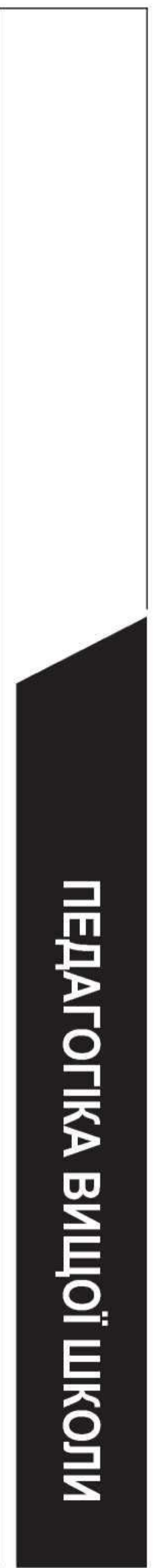


orientation, taking into account world experience and the principles of sustainable development» (ib.). Consequently, an important factor in the development of the national economy and business sphere is purposeful work to form the professional competence of future bachelors of entrepreneurship, trade, and exchange activity.

The integral competence of specialists of this profile according to the Higher Education Standard of Ukraine (Field of knowledge: 07 «Management and Administration» Specialty: 076 «Entrepreneurship, Trade, and Exchange Activity») is defined as the ability to solve complex specialized tasks and problems in the fields of entrepreneurship, trade, and exchange activity or in the learning process, which provides the application of theories and methods of organization and functioning of entrepreneurial, trade, exchange structures and is characterized by complexity and uncertainty of conditions» (Standard, 2018). Taking into account the European integration processes that take place in the economic, trade, and sociocultural space of the state, future bachelors of entrepreneurship, trade, and exchange activity should be aware of the latest forms and methods of organizing and conducting foreign economic activity of entrepreneurial, trade, and exchange structures, taking into account the market conditions.

Future specialists in entrepreneurship, trade, and exchange activity will be competitive in the labor market, provided that the economic competence is formed as a necessary component of professional competence. Accordingly, the structure of the economic competence of applicants for the first bachelor's degree in the specialty 076 «Entrepreneurship, Trade, and Exchange Activity» of the educational program «Commodity and Commercial Activity» requires a special study.

Analysis of current research. Theoretical and methodological foundations for the de- velopment of the economic competence of specialists in various fields are presented in the works of domestic and foreign scientists. V. Madzihon investigates the formation of professional knowledge of future economic specialists in the system of lifelong education as an important prerequisite for the development of the knowledge economy; N. Kostyna and V. Prystupa explore the economic competence as a component of the professional competence of future engineers. K. Dorokhin, Yu. Dorokhin, O. Serheiev consider the formation of the economic competence of bachelors of service, O. Bohonis investigates those of future specialists of hotel and restaurant service, V. Moskov studies those of future skilled construction workers.

The problem of formation of the economic competence of future teachers is considered by such scientists as T. Hutsan, V. Kurok, O. Padalka, T. Kondratenko, O. Khlopotova, and others. Researchers focus on the fact that this competence is a concept of «dynamic, multifaceted, and multidimensional, the content of which correlates with socio-economic, technical, and technological development» (Kurok, 2019, p. 24).

The essence, content, and structure of the economic competence of students during their professional training in higher education institutions are covered in the scientific works of L. Voropaieva, K. Ovakymian, Yu. Puzyienko, A. Tairova.

The analysis of the literature shows that theoretical and methodological aspects of the formation of the economic competence of future bachelors of entrepreneurship, trade, and exchange activity have not received sufficient coverage in the scientific discourse.

The purpose of the article is to characterize the structure of the economic competence of future bachelors of entrepreneurship, trade, and exchange activity of the educational program «Commodity and Commercial Activity».

Research methodology and methods. The study is based on the leading provisions 
of competency, systemic, activity-based methodological approaches, methods of analysis of regulatory documents, scientific literature on the problems of professional training of future specialists in the economic sphere, analysis, synthesis, and generalization of theoretical and practical foundations for the formation of the economic competence of future bachelors of entrepreneurship, trade, and exchange activity.

\section{Presentation of the main material.}

In modern conditions, the competency approach is considered as the methodological basis for the development of theory and practice of higher education, the development, and implementation of higher education standards for the training of specialists in various fields. According to the National Education Glossary, competence is «a dynamic combination of knowledge, skills, and practical skills, ways of thinking, professional, ideological and civic qualities, moral and ethical values, which determines a person's ability to successfully carry out professional and further educational activities and is the result of training on a certain level of higher education» (National Educational Glossary, 2014, p. 28 - 29).

Competence is an integrative quality of a person, namely: it ensures the effectiveness of life in a broad sense and professional activity in particular. At the same time, the essence of professional activity determines the subject content of competence (professional and managerial, communicative and informational, economic and social, and other competence). The competency approach allows moving from qualification requirements in the assessment of the readiness of a specialist and his professional activity to competencies, in particular in the economic training, to determine their structure and content.

Economic culture, the economic competence of graduates of higher education in the context of globalization and informatization of all spheres of social life is an impor- tant indicator of social and professional success in the modern labor market. The economic component of education allows a person to master the means of a balanced assessment of the resources and values of human capital, as well as the methods of competent choice of their life path. The study of the features of the economic culture in the context of market transformation led A. Suriak to the conclusion that in modern conditions there is a real contradiction between the readiness of economic entities to choose a market type of economic behavior and the need for a market type of economic behavior. This contradiction can be resolved through the development of economic consciousness, through the knowledge of economic laws, the formation of new value orientations, in-depth study of the rules governing economic activity, and the development of economic thinking in search for forms of economic behavior recognized by the market (Suriak, 2001).

The basis of the professional competence of future bachelors of entrepreneurship, trade, and exchange activity of the educational program «Commodity and Commercial Activity» is the system of competencies defined by the Higher Education Standard of Ukraine (Higher Education Standard, 2018) and the corresponding educational programs developed by higher education institutions to the professional training of specialists of the specified profile. It is important to note that each competence is a set of theoretical knowledge, practical skills, and abilities, as well as values, responsibility, readiness to realize one's own potential in future professional activities, and professional growth.

The applicant of the first bachelor's degree in the educational program «Commodity and Commercial Activity» must be able to possess not only direct professional skills but also indirect economic skills and abilities. First of all, he must be able to control the movement of inventory of entrepreneurial, trade, 
and exchange structures, minimize costs associated with the production process, help reduce the circulation of low-quality and unsafe goods, assess market conditions and performance of entrepreneurial, trade, and exchange structures, taking into account risks, participate in the implementation of e-commerce technology to organize highly efficient commercial activities of enterprises.

The educational program «Commodity and Commercial Activity» (Educational Program, 2020) is aimed at the formation of modern theoretical knowledge, skills, and practical mastery of skills in entrepreneurship, trade, and exchange activity for their application in solving complex professional tasks related to the ability to:

- determine the consumer properties of goods, analyze the assortment and assess the assortment policy of the enterprise, assess the quality, identify and prevent falsification of raw materials, materials, goods; organize trade and commercial activity, choose rational distribution channels for the goods, work with partners; analyze and forecast commodity market conditions; manage the quality and range of goods;

- understand the essence of the consumer protection process; implement and ensure the development of quality and safety management systems at enterprises, assess the conformity of products according to the requirements of the national system of state control;

- use theoretical knowledge and practical skills of classification of goods according to the commodity nomenclature of foreign economic activity;

- apply business innovations.

Analysis of the scientific literature allows us to identify various scientific approaches to understanding the essence of professional competence in the context of the formation of the economic competence of students in entrepreneurship, trade, and exchange activity: a functional-activity ap- proach that considers competence as a unity of theoretical and practical readiness to carry out activities (in our case, economic), to perform professional functions, in which the main parameters of professional competence are set by the functional structure of activity, including several theoretical and practical skills: analytical, prognostic, projective, reflexive, organizational, communicative, etc.; an axiological approach that considers competence as an educational value. Professional competence involves the introduction of a person into the general cultural world of values (in particular, economic ones), and it is in this space that a person realizes himself as a specialist and professional; individualoriented approach, which determines the focus of the educational process on the active cooperation of teachers and students in the process of mastering economic knowledge and the formation of relevant skills and abilities, taking into account the individual abilities of students, increasing their independence and variability, motivational focus, intensification of educational activities; $a$ universal approach to understanding the essence of professional competence lies in the fact that this category is clearly not related to either general or professional education. Accordingly, competence is related to basic qualifications and at the same time allows a person to navigate in a wide range of issues that are not limited to a narrow specialization, which ensures the socio-economic and professional mobility of the individual, openness to change and creative search, the ability to self-expression and self-creation, readiness and ability to update their knowledge; a creative approach considers professional competence as the level of creative realization of professionalism, communication skills and autonomy, which is understood as independence, right, and responsibility for making independent decisions in their professional activities. 
The scientific literature presents different approaches to defining the essence and structure of the economic competence of specialists in various fields. O. Padalka, O. Shpak, and V. Prystupa believe that the economic competence reflects an integrative characteristic of a person, which includes knowledge and skills that are realized through economically important personality traits in the process of economic activity (Padalka, 2011). V. Moskov notes that «an economically competent qualified construction worker is a specialist who has a combination of professional and economic knowledge and practical skills, experience in the economic culture of thinking, shows a strong need and interest in the professional and economic competence» (Moskov, 2017, p. 6).

K. Ovakymian, who studied the development of the economic competence of students of higher education, understands it as «a set of economic knowledge, skills, and abilities, the possession of which allows a university student to make economically justified decisions in various socially determined situations» (Ovakymian, 2010, p. 11). According to the tasks of the study of the economic competence of future technology teachers, V. Kurok and T. Kondratenko note that «the economic competence is characterized by a set of educational elements that cover the system of economic knowledge, skills, and value attitudes towards economic knowledge. It is they who ensure an individual's awareness of the economic mechanism and its functioning in the context of production and distribution, exchange and consumption, effective use of the results of human labor» (Kurok, Kondratenko, 2019, p. 25). O. Khlopotova defines the economic competence of a technology teacher as «an integral professional and personal quality generated by the content and creative activity of a student as the subject of acquiring his own experience of economic activity in the process of professional training, charac- terized by the presence of integrated professional knowledge and skills, professional moral and value motivation, which allows us to talk about the ability to effectively carry out professional activities as a teacher of technology and entrepreneurship» (Khlopotova, 2005, p. 20).

Taking into account the scientific provisions of the competency approach, the essential features of the economic competence of specialists in various fields, the regulatory requirements of the educational program «Commodity and Commercial Activity», the economic competence of bachelors of entrepreneurship, trade, and exchange activity is considered as a component of professional competence, integrative education, the main characteristics of which is the presence of fundamental scientific and applied knowledge in the field of economics in students, knowledge of legal norms that determine economic activity, the specifics of business communication, basic economic concepts, the formation of skills and abilities necessary to solve economic problems associated with future professional activities, readiness to carry out effective economic activities in the future profession, a high level of development of relevant personal qualities in modern conditions of market competition.

The identification of structural components of the economic competence of specialists of different profiles in scientific research is presented taking into account theoretical and methodological foundations of the competency approach in education, the profile of the corresponding professional training. E. Zeer noted that «in the modern post-industrial society, the social and professional functions of workers have changed significantly; such qualities as organization, independence, responsibility, practical intelligence, reliability, ability to plan, solve problems, etc. turned out to be in demand» (Zeer, Symaniuk, 2005, p. 28). It is impor- 
tant to emphasize that to determine the structure of professional competence of future specialists, E. Zeer stressed the need to take into account the basic functional subsystems of a personality according to B. Lomov, who identifies the following subsystems: «cognitive, which includes cognitive processes: perception, memory, thinking, imagination; regulatory, which includes emotional and volitional processes and provides the subject's ability to self-regulation, self-control, influence the behavior of other people; communicative, which is realized in communication and interaction with other people» (Zeer, Symaniuk, 2005, p. 28).

L. Voropaieva presents a model of an economically competent specialist in the unity of such components as the requirements for a specialist-economist, basic and special competencies, socially significant and professionally important qualities (Voropaieva, 2007). In the structure of the economic competence of future technology teachers, V. Kurok and T. Kondratenko distinguish motivational, cognitive, operational-activity, effective-reflexive components (Kurok, Kondratenko, 2019, p. 25), O. Khlopotova distinguishes motivational, cognitive, behavioral, value-semantic and emotional-volitional components (Khlopotova, 2005 , p. 13). K. Ovakymian defines the following components in the structure of the economic competence of students of higher education institutions: cognitive (a system of economic knowledge, ideas about ways of economic functions in society), emotional and value (a system of value orientations in the economic sphere, motivation, economic feelings and beliefs); activity-creative (experience of using economic knowledge, skills to achieve economic goals) (Ovakimian, 2010, p. 11). The analysis of the presented approaches to the structure of the economic competence of specialists in various fields testifies to the representation of B. Lomov's scientific provisions on the main functional subsystems of the personality, substantiation of the corresponding structure based on such content-forming categories as knowledge, motivation, value orientations, experience, and personal qualities.

The economic competence of students of the specialty 076 «Entrepreneurship, Trade, and Exchange Activity» is the basic foundation of all special competencies defined by the relevant industry standard (Standard, 2018) and includes such components as value-motivational, cognitive, personal, activity-communicative.

The value-motivational component of the economic competence of bachelors of entrepreneurship, trade, and exchange activity necessitates the development of motives and needs that serve as an impetus for the acquisition of modern economic knowledge, the formation of readiness for economic activity, personal and professional development. It is the motivation that determines the characteristics of human behavior, its focus on the implementation of relevant social and professional tasks. In the context of the competency approach in education, special attention is paid to the internal motivation of the individual, since, according to J. Raven, the assessment of «cognitive abilities» without connection with the goal pursued by the individual does not make sense (Raven, 2002).

The success of the professional activity of a specialist of any profile is due to the presence of appropriate values, value and semantic orientations, which act as a regulator of individual behavior, mediating its relationship with the social world and professional environment. The personal value system is individualized, formed under the influence of many external and internal factors, and, accordingly, significantly affects the conscious and unconscious acceptance of professional values by a future specialist. In the context of the formation of the economic competence, it is also important to focus on group values and the economic values of society as a whole. 
The cognitive component is aimed at developing students' cognitive activity in the field of economic knowledge. The basis for the successful performance of professional functions by future specialists in entrepreneurship, trade, and exchange activity in a competitive environment is deep theoretical and methodological knowledge of economics, management, entrepreneurship, as well as the regulatory and legal framework of entrepreneurial, trade, and exchange activity, personnel management, etc. Ensuring the necessary theoretical and practical level of development of the economic competence of students of the specialty 076 «Entrepreneurship, Trade, and Exchange Activity» must be considered in the field of general economic training: the economic theory, macroeconomics, microeconomics, the theory of economic analysis; and professionally oriented training: trade entrepreneurship, accounting, and auditing, exchange activities; organization of trade and management of the commercial activity, foreign economic activity.

Within the framework of the cognitive component of the economic competency of future specialists of the studied profile, the information aspect of professional training is of significant importance, namely: providing free access in the process of the classroom, extracurricular, independent work to information on the role of economic knowledge in the modern world, market relations in the global society; analysis of national and international laws, programs, conventions, etc. on the economic development of the country and the world. Information support is a prerequisite for solving the problems of the formation of the economic competence of students, since, firstly, high-quality and timely information reflects all the diversity of the economic life of society; secondly, thanks to the information, each student has the opportunity to feel their belonging to the development of society and responsibility for its well-being; thirdly, by studying the relevant information, the socio-economic experience of mankind is mastered; fourth, it is information that encourages students to actively participate in the socio-economic transformations of the state.

The personal component of the economic competence of bachelors of entrepreneurship, trade, and exchange activity determines particular importance of sociopsychological qualities of students: the ability to achieve the goal, mobilize energy, convince, have leadership skills, be persistent, proactive, energetic, decisive, ambitious, etc. The ability to control consciously the results of their activities and the level of their own development, assess personal achievements, self-confidence, mobility, and more should be noted. In our opinion, the personal component of the economic competence is a regulator of the personal achievements of future specialists, the basis for the development of reflexive abilities, forecasting the results of professional activity.

The activity-communicative component of the economic competence is associated with economic skills, the communicative competence of future specialists in the field of entrepreneurship and trade, which allows considering the economic competence within the framework of the activity and functional approaches. It covers ways of actions (means, forms, methods, techniques of economic influence), personal behavior in the process of economic interaction, professional tact, communication skills, the ability to resolve conflict-free professional situations of economic orientation, etc.

For future specialists in this field, the ability to diagnose and analyze the course of economic processes is important: estimation of volumes, types of work, planning of physical and material costs, modeling of own activities; the ability to develop and make a decision, that is, to identify goals, formulate a problem and criteria, generate alternatives, evaluate alternatives according to criteria; the 
ability to implement decisions, i.e. to communicate decisions to executors, to control the implementation of decisions; possession of innovative management technologies in market conditions, etc.

Communicative skills, the professional orientation of speech provide awareness of communication as a means of achieving goals in interpersonal relationships, development, and self-development of the individual, stimulating the formation of important personal and professional qualities necessary for self-realization in social relations.

It is clear that each of the above components of the economic competence of students of the specialty 076 «Entrepreneurship, Trade, and Exchange Activity» can not exist autonomously, wherefore, we consider the structure of the studied phenomenon comprehensively, in the interaction of certain components with each other.

Conclusions and prospects for further research. The modern socio-cultural and economic situation objectively sets high requirements for the professional competence of specialists in the field of entrepreneurship and trade, who must have a high level of the economic competence, be capable of productive activity in an innovative technical and economic environment. The content of the economic competence of students of the specialty 076 «Entrepreneurship, Trade, and Exchange Activity» is holistic, formed by the economic experience of the individual and creates the readiness to participate in economic activities, including knowledge of theoretical foundations of entrepreneurial activity; understanding the nature of economic connections and relationships; ability to analyze specific situations inherent in entreprenerial, trade, exchange activities in the process of professional activity.

Prospects for further research are associated with the definition of pedagogical conditions, technologies, forms, and methods of teaching students of the specialty 076 «Entrepre- neurship, Trade, and Exchange Activity», aimed at the formation of the economic competence.

\section{References}

Voropaeva, L. V. (2007). Vospitanie ekonomicheski kompetentnoho spetsialista $\mathrm{V}$ usloviiakh profilizatsii obrazovaniia [The Education of an Economically Competent Specialist in the Conditions of Education Profiling]. Extended abstract of candidate's thesis. Stavropol [in Russian].

Zeer, E. F. \& Symaniuk, E. (2005). Kompetentnostnyi podkhod k modernizatsii professionalnoho obrazovaniia [Competence Approach to the Modernization of Vocational Education]. Vysshee obrazovanie $v$ Rossii - Higher education in Russia, 4, 23-29 [in Russian].

Kurok, V. \& Kondratenko, T. (2019). Zmist ta struktura ekonomichnoi kompetentnosti maibutnikh uchyteliv tekhnolohii [The Content and Structure of Economic Competence of Future Technologies Teachers]. Molod i rynok - Youth and the market, 3, 23-27 [in Ukrainian].

Moskov, V. A. (2017). Formuvannia ekonomichnoi kompetentnosti maibutnikh kvalifikovanykh robitnykiv budivelnoho profiliu [Formation of Economic Competence of Skilled Workers Building Profiles]. Extended abstract of candidate's thesis. Vinnytsia: Vinnytsia State Pedagogical University named after Mykhailo Kotsiubynsky [in Ukrainian].

Natsionalna stratehiia rozvytku osvity v Ukraini na period do 2021 roku [National Strategy for the Development of Education in Ukraine until 2021]. Retrieved from https://zakon.rada.gov.ua/laws/show/344/20 13\#n10 [in Ukrainian].

Zakharchenko, V. M., Kalashnikova, S. A. \& Luhovyi, V. I. (2014). Natsionalnyi osvitnii hlosarii: vyshcha osvita [National Education Glo-ssary: Higher Education]. (Editor: Kremen V. H.) Kyiv : TOV «Vydavnychyi dim «Pleiady» [Publishing House «Pleiades» LLC] [in Ukrainian]. 
Ovakimyan, E. E. (2010). Razvitie ekonomicheskoy kompetentnosti studentov VUZov [The Development of the Economic Competence of the University Students]. Extended abstract of candidate's thesis. Chelyabinsk [in Russian].

Osvitnia prohrama «Tovaroznavstvo i komertsiina diialnist» pershoho (bakalavrskoho) rivnia vyshchoi osvity za spetsialnistiu 076 «Pidpryiemnytstvo, torhivlia ta birzhova diialnist» haluzi znan 07 «Upravlinnia ta administruvannia» [Educational Program «Commodity and Commercial Activity» of the First (Bachelor's) Level of Higher Education in the Specialty 076 «Entrepreneurship, Trade, and Exchange Activity» in the Field of Knowledge 07 «Management and Administration»]. (2020). Starobilsk. Retrieved from

http://uguniv.edu.ua/wp-content/uploads/2020/07/ op_076_torg_birja_kom_diyaln_2020_dz.pdf [in Ukrainian].

Padalka, O. S., Shpak, O.T. \& Prystupa, V.V. (2011). Dydaktyko-matema-tychni osnovy formuvannja ekonomichnoji kompetentnosti: navch. posib. [Didactic and Mathematical Foundations of the Formation of Economic Competence]. Kyiv: Vydvo NPU im. M. P. Dragho-manova [in Ukrainian].

Raven, Dzh. (2002). Kompetentnost v sovremennom obshchestve: vyiavlenie, razvitie irealizatsiia [Competence in Modern Society: Identification, Development, and Implementation]. Moscow: Kohyto-Tsentr [in Russian].

Standart vyshchoi osvity Ukrainy. Riven vyshchoi osvity: Pershyi (bakalavrskyi) riven. Haluz znan: 07 «Upravlinnia ta administruvannia». Spetsialnist: 076 «Pidpryiemnytstvo, torhivlia ta birzhova diialnist» [The Standard of Higher Education of Ukraine. Level of Higher Education: First (Bachelor's) Level. Field of Knowledge: 07 «Management and Administration». Specialty: 076 «Entrepreneurship, Trade, and Exchange Activity»]. Order of the Ministry of Education and Science of Ukraine 1243 from 2018/11/13. Kyiv, 2018. Retrieved from https://mon.gov.ua/storage/app/media/vishchaosvita/zatverdzeni\%20standarty/12/21/076pidpriemnitstvo-torgivlya-ta-birzhovadiyalnist-bakalavr.pdf [in Ukrainian].

Suriak, A. V. (2001). Ekonomichna kultura $\mathrm{v}$ umovakh rynkovoi transformatsii [The Economic Culture in the Conditions of Market Transformation]. Extended abstract of candidate's thesis. Kyiv [in Ukrainian].

Hlopotova, E. V. (2005). Formirovanie ekonomicheskoy kompetentnosti budushchego uchitelya tekhnologii i predprinimatelstva (spetsialnost $\ll 030600.00$ - Tekhnologiya i predprinimatelstvo») [The Formation of the Economic Competence of the Future Teacher of the Technologies and Entrepreneurship]. Extended abstract of candidate's thesis. Moscow [in Russian]. $* * *$

Морозова М. М. Структура економічної компетентності бакалаврів підприємництва, торгівлі та біржової діяльності освітньої програми «Товарознавство і комерційна діяльність»

У статті на основі Стандарту вищої освіти (Спеціальність: 076 «Підприємництво, торгівля та біржова діяльність»), освітньої програми «Товарознавство і комерційна діяльність» схарактеризовано основні вимоги до професійної підготовки бакалаврів підприємництва, торгівлі та біржової діяльності. Представлено сучасні наукові підходи до визначення сутності та структури економічної компетентності фахівців різного профілю.

3 урахуванням положень компетентнісного підходу, відповідного стандарту визначено сутність економічної компетентності майбутніх фахівців сфери підприємництва, торгівлі та біржової діяльності. 3'ясовано, що економічна компетентність характеризується сукупністю освітніх елементів, охоплюючи систему економічних знань, умінь, навичок, ціннісного ставлен- 
ня до економічних знань. Розкрито структурні компоненти економічної компетентності майбутніх фахівців означеної сфери: ціннісно-мотиваційний, когнітивний, особистісний, діяльнісно-комунікативний.

Ключові слова: майбутні фахівці 3 підприємництва, торгівлі та біржової діяльності, освітня програма «Товарознавство і комерційна діяльність», компетентнісний підхід, економічна компетентність, структура економічної компетентності.

Морозова М. Н. Структура экономической компетентности бакалавров предпринимательства, торговли и биржевой деятельности образовательной программы «Товароведение и коммерческая деятельность»

В статье на основе стандарта высшего образования (специальность: 076 «Предпринимательство, торговля и биржевая деятельность»), образовательной программы «Товароведение и коммерческая деятельность» охарактеризованы основные требования к профессиональной подготовке бакалавров предпринимательства, торговли и биржевой деятельности. Представлены современные научные подходы к определению сущности и структуры экономической компетентности специалистов разного профиля.

С учетом компетентностного подхода, соответствующего стандарта определена сущность экономической компетентности будущих специалистов сферы предпринимательства, торговли и биржевой деятельности. Выяснено, что экономическая компетентность характеризуется совокупностью образовательных элементов, включая систему экономических знаний, умений, навыков, ценностного отношения к экономическим знаниям. Раскрыты структурные компоненты экономической компетентности будущих специалистов обозначенной сферы: ценностно-мотивационный, когни- тивный, личностный, деятельностнокоммуникативный.

Ключевые слова: будущие специалисты по предпринимательству, торговле и биржевой деятельности, образовательная программа «Товароведение и коммерческая деятельность», компетентностный подход, экономическая компетентность, структура экономической компетентности.

Morozova M. M. Structure of the Economic Competence of Bachelors of Entrepreneurship, Trade, and Exchange Activity of the Educational Program «Commodity and Commercial Activity»

The article characterizes the basic requirements for the professional training of bachelors of entrepreneurship, trade, and exchange activity based on the Standard of Higher Education (Specialty: 076 «Entrepreneurship, Trade, and Exchange Activity»), the educational program «Commodity and Commercial Activity». The paper presents modern scientific approaches to determining the essence and structure of the economic competence of specialists in various fields.

Taking into account the competency approach and the relevant standard, the essence of the economic competence of future professionals in the field of entrepreneurship, trade, and exchange activity is determined. It has been discovered that the economic competence is characterized by a set of educational elements, including the system of economic knowledge, skills, values, attitudes towards economic knowledge. The structural components of the economic competence of future specialists in this field have been revealed: value-motivational, cognitive, personal, activity-communicative.

Key words: future specialists in entrepreneurship, trade, and exchange activity, educational program «Commodity and Commercial Activity», competency approach, economic competence, structure of the economic competence. 